\title{
UPAYA MENINGKATKAN HASIL BELAJAR PKN PADA MATERI KEBEBASAN BERORGANISASI DENGAN MENGGUNAKAN PEMBELAJARAN KOOPERATIF TIPE STAD SISWA KELAS V SD NEGERI 165725 KOTA TEBING TINGGI
}

\author{
Renti Sinaga \\ Surel:rentisinaga@gmail.com
}

\begin{abstract}
This study aims to improve the learning outcomes of civic education on the material freedom to organize students of class V SD Negeri 165725 Tebing Tinggi city by using cooperative learning model type STAD 2015/2016 learning year. This research is classroom action research (PTK) The subject of this research is the students of grade V SD Negeri 165725 Kota Tebing Tinggi, which is 24 students. Data analysis in this research was collected by using observation sheet, interview and test. Learning using STAD type cooperative learning model can improve the learning outcomes of civic education on the material freedom of association of class $V$ students $S D$ Negeri 165725 Tebing Tinggi year 2015/2016 learning.
\end{abstract}

Keywords: Learning Outcome, Freedom of Organization, STAD

\begin{abstract}
ABSTRAK
Penelitian ini bertujuan untuk meningkatkan hasil belajar pendidikan kewarganegaraan pada materi kebebasan berorganisasi siswa kelas V SD Negeri 165725 kota Tebing Tinggi dengan menggunakan model pembelajaran kooperatif tipe STAD tahun pembelajaran 2015/2016. Penelitian ini adalah penelitian tindakan kelas (PTK). Subjek pada penelitian ini adalah siswa kelas V SD Negeri 165725 kota Tebing Tinggi yang berjumlah 24 siswa. Analisis data pada penelitian ini dikumpulkan dengan menggunakan lembar observasi, wawancara dan tes. Pembelajaran dengan menggunakan model pembelajaran kooperatif tipe STAD dapat meningkatkan hasil belajar pendidikan kewarganegaraan pada materi kebebasan berorganisasi siswa kelas V SD Negeri 165725 Tebing Tinggi tahun pembelajaran 2015/2016.
\end{abstract}

Kata Kunci: Hasil Belajar, Kebebasan Berorganisasi, STAD

\section{PENDAHULUAN}

Pembelajaran merupakan
proses belajar-mengajar yang
merupakan perpaduan antara dua
aspek yang saling mempengaruhi,
yaitu aspek belajar yang dilakukan

oleh siswa sebagai peserta didik dan aspek mengajar yang dilakukan oleh guru sebagai pendidik. Proses belajar yang terjadi berorientasi pada apa yang harus dilakukan oleh peserta didik sebagai subjek yang berperan

Guru SD Negeri 165725 Tebing Tinggi 
membangun pengetahuan, sedangkan proses mengajar beorientasi pada apa yang harus dilakukan oleh guru sebagai fasilitator pembelajaran. Kedua aspek ini akan terjadi secara bersamaan dan berkolaborasi secara terpadu menjadi suatu kegiatan dalam proses interaksi antara guru dengan siswa, serta antara siswa dengan siswa di saat pembelajaran berlangsung. Dalam proses pembelajaran ini, baik guru maupun siswa bersama-sama memainkan perannya masing-masing untuk terwujudnya tujuan pembelajaran yang telah ditetapkan. Proses pembelajaran yang dilakukan guru memang dibedakan keluasan cakupannya, tetapi dalam konteks kegiatan belajar mengajar mempunyai tugas yang sama. Maka tugas mengajar bukan hanya sekedar menuangkan bahan pelajaran, tetapi teaching is primarily and always the stimulation of learner (Wetherington, 1986:131-136), dan mengajar tidak hanya dapat dinilai dengan hasil penguasaan mata pelajaran, tetapi yang terpenting adalah perkembangan pribadi anak, sekalipun mempelajari pelajaran yang baik, akan memberikan pengalaman membangkitkan bermacam-macam sifat, sikap dan kesanggupan yang konstruktif.

Kualitas pendidikan, sebagai salah satu pilar pengembangan sumberdaya manusia yang bermakna, sangat penting bagi pembangunan nasional. Bahkan dapat dikatakan masa depan bangsa bergantung pada keberadaan pendidikan yang berkualitas yang berlangsung di masa kini. Pendidikan yang berkualitas hanya akan muncul dari sekolah yang berkualitas. Oleh sebab itu, upaya peningkatan kualitas sekolah merupakan titik sentral upaya menciptakan pendidikan yang berkualitas demi terciptanya sumber daya manusia yang berkualitas pula. Dengan kata lain upaya peningkatan kualitas sekolah adalah merupakan tindakan yang tidak pernah terhenti, kapanpun, dimanapun dan dalam kondisi apapun.

Pelajaran pendidikan kewarganegaraan bagi sebahagian besar siswa SD sekarang ini umumnya dianggap sebagai pelajaran yang sangat sulit untuk dipahami, memerlukan penalaran yang sangat baik serta ketekunan dan konsentrasi yang penuh dari siswa. Kondisi ini membuat sebagian besar siswa kurang mampu memahami materi pelajaran yang ada dalam pelajaran pendidikan kewarganegaraan. Selain itu, kondisi ini juga membuat siswa kurang berminat untuk mengikuti pelajaran ini. Siswa merasa bahwa pembelajaran pendidikan kewarganegaraan yang diberikan oleh guru selama ini kurang menarik.

Oleh sebab itu guru bidang studi pendidikan kewarganegaraan hendaknya dapat mengemas seperangkat pembelajaran pendidikan kewarganegaraan dengan lebih menarik lagi agar tidak menimbulkan 
kejenuhan bagi siswa, sehingga siswa dapat lebih bersemangat mengikuti dan menyimak pelajaran pendidikan kewarganegaraan dan dapat dengan mudah menerima serta memahami konsep-konsep pendidikan kewarganegaraan yang diajarkan. Permasalahan dan fakta yang terurai inilah melatar belakangi peneliti untuk melakukan penelitian tindakan kelas, di kelas V SD Negeri 165725 kota Tebing Tinggi. Peneliti memandang perlu mengembangkan metode pembelajaran yang dapat meningkatkan semangat dan motivasi siswa dalam belajar sehingga nilai pendidikan kewarganegaraan menjadi lebih baik dan meningkat. Pembelajaran kooperatif tipe STAD dirasa dapat menjawab permasalahan tersebut, sebab pembelajaran kooperatif tipe STAD ini mudah diterapkan, melibatkan aktivitas seluruh siswa tanpa harus ada perbedaan status, melibatkan peran siswa sebagai tutor sebaya dan mengandung unsur permainan serta peneguhan (reinforcement). Aktivitas belajar dengan permainan yang dirancang dalam pembelajaran kooperatif tipe STAD memungkinkan siswa dapat belajar lebih santai disamping menumbuhkan tanggung jawab, kerjasama, persaingan sehat dan keterlibatan belajar.

Berdasarkan paparan dan analisa di atas, maka peneliti tertarik untuk membuat penelitian dalam upaya meningkatkan hasil belajar pendidikan kewarganegaraan pada materi kebebasan berorganisasi. Adapun judul penelitian yang akan dilakukan adalah: "Upaya meningkatkan hasil belajar pendidikan kewarganegaraan pada materi kebebasan berorganisasi dengan menggunakan pembelajaran kooperatif tipe Students Team Achievement (STAD) siswa kelas V SD Negeri 165725 kota Tebing Tinggi tahun pembelajaran 2015/2016".

Berdasarkan uraian latar belakang masalah di atas, maka dapat diuraikan identifikasi masalah penelitian yaitu sebagai berikut:

1. Hasil belajar siswa pada pembelajaran pendidikan kewarganegaraan pada materi kebebasan berorganisasi masih sangat rendah.

2. Kurangnya keterlibatan siswa dalam proses belajar mengajar, dimana guru yang berperan aktif, sehingga siswa kurang antusias yang akhirnya mempengaruhi hasil belajarnya.

3. Minat dan perhatian siswa kepada pelajaran pendidikan kewarganegaraan yang kurang.

4. Motivasi dan semangat belajar siswa yang rendah karena metode mengajar yang dilakukan oleh guru masih sangat monoton dan konvensional.

Supaya penelitian ini tidak terlalu luas, maka batasan masalah pada penelitian ini adalah: Peningkatan hasil belajar pendidikan 
kewarganegaraan pada materi kebebasan berorganisasi dengan menggunakan model pembelajaran kooperatif tipe Students Team Achievement (STAD)

Berdasarkan uraian batasan masalah di atas, maka masalah dalam penelitian ini adalah: "Apakah dengan menggunakan model pembelajaran kooperatif tipe Students Team Achievement (STAD) dapat meningkatkan hasil belajar pendidikan kewarganegaraan pada materi kebebasan berorganisasi siswa kelas V SD Negeri 165725 kota Tebing Tinggi tahun pembelajaran 2015/2016?"

Adapun tujuan penelitian ini adalah: Meningkatkan hasil belajar siswa kelas V SD Negeri 165725 kota Tebing Tinggi pada pelajaran pendidikan kewarganegaraan pada materi kebebasan berorganisasi melalui model pembelajaran kooperatif tipe Students Team Achievement (STAD).

Hasil dari penelitian ini akan memberikan manfaat bagi perbaikan proses pembelajaran di sekolah, adapun manfaat dari penelitian ini adalah sebagai berikut:

1. Manfaat Teoritis

Penelitian ini diharapkan dapat menjadi sumbangan pemikiran dan bahan acuan bagi guru, pengelola, pengembangan, lembaga pendidikan dan penelitian selanjutnya.
2. Manfaat Praktis

Bagi peneliti / guru:

- Dapat menambah pengetahuan dan pengalaman guru (peneliti) dalam menerapkan model pembelajaran kooperatif tipe Students Team Achievement (STAD).

- Meningkatkan kualitas guru dalam melaksanakan tugas mengajar terutama dalam mengajar pendidikan kewarganegaraan.

- Merangsang guru-guru yang lain untuk melakukan pembelajaran yang kreatif dan menyenangkan bagi siswa.

Bagi siswa

- Dapat memberikan nuansa baru dalam proses pembelajaran khususnya pembelajaran pendidikan kewarganegaraan dengan menerapkan model pembelajaran kooperatif tipe Students Team Achievement (STAD) dan dapat meningkatkan hasil belajar pada materi kebebasan berorganisasi.

- Membantu siswa berfikir kritis, rasional dan kreatif dalam mengerjakan soal-soal baik secara individual maupun kelompok.

- Memberi peluang kepada siswa untuk lebih aktif mengembangkan potensi dirinya terutama dalam 
memberi pendapat-pendapat yang konstruktif positif untuk memecahkan masalah dalam pembelajaran pendidikan kewarganegaraan.

Bagi Sekolah

- Meningkatkan hasil belajar pendidikan kewarganegaraan di SD Negeri 165725 kota Tebing Tinggi sehingga mampu bersaing dengan sekolah sekolah yang lain.

Penelitian ini bermanfaat bagi sekolah karena dapat memberi masukan atau sumbangan penelitian bagi peneliti lain yang melakukan Penelitian Tindakan Kelas (PTK). Adapun defenisi operasional penelitian ini adalah:

1. Pembelajaran kooperatif adalah pembelajaran yang memberikan kesempatan kepada anak didik untuk bekerjasama dengan sesama siswa dalam tugas-tugas yang terstruktur.

2. Students Team Achievement (STAD) merupakan salah satu model pembelajaran kooperatif yang melakukan pengelompokan siswa dalam proses pembelajaran. Dengan model pembelajaran ini, siswa diperlakukan sebagai subjek belajar yang secara kreatif dan aktif melakukan aktivitas belajar dalam kelompok. Students Team Achievement (STAD) dapat diartikan sebagai tim siswa kelompok prestasi. Dalam hal ini, siswa belajar dalam tim atau kelompok yang telah dibentuk sehingga orientasi pembelajarannya mengarah pada peningkatan kemampuan anggota kelompok secara merata. Dengan model ini, setiap siswa dalam suatu kelompok mendapatkan kesempatan yang sama untuk meningkatkan hasil belajarnya.

\section{METODE PENELITIAN}

Yang menjadi subjek penelitian ini adalah siswa kelas $\mathrm{V}$ SD Negeri 165725 jalan Jenderal Sudirman kota Tebing Tinggi yang berjumlah 24 siswa dengan rincian 14 perempuan dan 10 laki-laki. Rata rata usia siswa ini adalah 10-11 tahun. Sebagian besar siswa adalah masyarakat yang bermukim di sekitar sekolah tempat penelitian dilakukan.

Penelitian ini dilakukan di SD Negeri 165725 yang beralamat di jalan Jenderal Sudirman kota Tebing Tinggi. Penelitian ini dilakukan pada semester pertama tahun pembelajaran 2015/2016 yaitu bulan Januari sampai dengan Mei 2016.

Penelitian yang penulis lakukan ini adalah penelitian tindakan kelas (PTK), karena permasalahan yang diangkat adalah permasalahan yang dijumpai langsung oleh penulis ketika mengajarkan mata pelajaran matematika di dalam kelas. Model Penelitian Tindakan kelas yang dipakai adalah model Lewins. Penelitian ini direncakan 
dilaksanakan sebanyak 2 siklus, dan dalam setiap siklusnya terdapat kegiatan: 1. Perencanaan, 2. Pelaksanaan, 3. Pengamatan, 4. Refleksi.

Alat pengumpul data dalam penelitian ini adalah tes yang disusun oleh Guru yang fungsinya adalah: (1) Untuk menentukan seberapa baik siswa telah menguasai bahan pelajaran yang telah diberikan dalam waktu tertentu; (2) Untuk menentukan apakah suatu tujuan telah tercapai; dan (3) Untuk memperoleh suatu nilai (Arikunto, Suharismi, 2002:19). Sedangkan tujuan dari tes adalah untuk mengetahui ketuntasan belajar siswa secara individual maupun secara klasikal. Disamping itu untuk mengetahui letak kesalahan-kesalahan yang dilakukan siswa sehingga dapat dilihat dimana kelemahannya, khususnya pada pokok bahasan materi ajar yang belum tercapai. Untuk memperkuat data yang dikumpulkan, maka juga digunakan metode observasi (pengamatan) yang dilakukan oleh teman sejawat untuk mengetahui dan merekam aktifitas Guru dan siswa dalam proses belajar mengajar.

Untuk mengetahui kefektifan
suatu metode dalam kegiatan
pembelajaran perlu diadakan analisis
data. Pada penelitian in
menggunakan teknik analisis
dekriptif kualitatif, yaitu suatu metode
penelitian yang bersifat menggambar
-kan kenyataan atau fakta sesuai
dengan data yang diperoleh dengan

tujuan untuk mengetahui pemahaman yang dicapai siswa, juga untuk memperoleh respon siswa terhadap kegiatan pembelajaran serta aktivitas siswa selama proses pembelajaran.

Penelitian ini dapat dikatakan berhasil dan tidak perlu dilanjutkan kepada siklus berikutnya apabila hasil dari tes siswa yang berjumlah 24 siswa telah sesuai dengan KKM yang ditentukan yaitu 70,00 atau tingkat ketuntasan kelas diatas $85 \%$ dari 24 siswa. Selain itu jika dilihat dari partisipasi dan kemauan serta keseriusan siswa dalam mengerjakan tugas yang diberikan guru diatas $85 \%$ dari jumlah seluruh siswa.

\section{HASIL DAN PEMBAHASAN}

Berdasarkan hasil tes yang dilakukan setelah siklus I selesai dilaksanakan sudah makin meningkat jika dibandingkan dengan hasil perolehan nilai pada kegiatan pra siklus. Jika pada pra siklus jumlah siswa yang berada pada interval nilai 50-59 pada pra siklus berjumlah 6 siswa (25\%) maka pada siklus I berkurang menjadi 1 siswa $(4,16 \%)$, untuk interval nilai 70-79 jika pada pra siklus hanya 8 siswa (33,3\%) maka pada siklus I meningkat menjadi 12 siswa (50\%), interval 8089 jika pada pra siklus hanya 2 siswa $(8,33 \%)$ maka pada siklus I meningkat menjadi 3 siswa $(12,5 \%)$ dan 90 - 100 jika pada pra siklus tidak ada siswa satu orangpun yang memperoleh nilai itu maka pada 
siklus I ada 2 siswa $(8,33 \%)$ yang berhasil memperolehnya.

Dari data di atas terlihat kemampuan siswa meningkat setelah guru mengajar pendidikan kewarganegaraan materi kebebasan berorganisasi dengan menggunakan model pembelajaran kooperatif tipe Students Team Achievement (STAD). Hal ini juga bisa kita lihat pada persentase pencapaian secara klasikal terhadap KKM yang telah ditentukan. Jika pada kegiatan pra siklus pencapaian presentase secara klasikal hanya mencapai $41,66 \%$ maka pada siklus I telah mencapai $70,83 \%$ terjadi peningkatan sekitar 29,17\% jika dibandingkan dengan pra siklus.

\section{Observasi}

Pengamatan dalam penelitian ini dilihat dari berbagai instrumen penelitian, antara lain hasil tes kognitif siswa, lembar pengamatan terhadap ketrampilan siswa, dan pengamatan terhadap aktivitas siswa selama proses pembelajaran berlangsung. Dari hasil pengamatan yang dilakukan oleh observer dengan menggunakan lembar observasi yang telah disiapkan terlihat guru (peneliti) sudah melaksanakan seluruh aspek yang menjadi point pada lembar observasi. Kendala yang masih terlihat saat guru mengajar pada siklus I adalah masih ada siswa yang belum serius ketika dimintakan mencari jawaban dari tugas yang diberikan guru melalui kelompok. Siswa masih terlihat termenung sambil memainkan pulpennya. Hal ini disebabkan siswa belum terbiasa saat diskusi harus mengemukakan pendapat. Sebab selama ini saat berdiskusi biasanya teman yang lebih pintar selalu memonopoli atau lebih prioritas mengerjakan seluruh tugas yang diberikan, sementara siswa yang lain hanya duduk diam saja.

Refleksi dilakukan untuk mengetahui sejauh mana keberhasilan dari penerapan pembelajaran dengan menggunakan pembelajaran kooperatif tipe Students Team Achievement (STAD) yang telah dilakukan, mengetahui hasil belajar siswa pada siklus I, menganalisis aktivitas individual siswa dalam kelompok, mengetahui kendalakendala pada siklus I, serta mencari solusi dari kendala yang dihadapi untuk perbaikan pada siklus berikutnya.

Adapun hasil refleksi yang dilakukan pada siklus I adalah sebagai berikut : (a) masih ada siswa kurang serius atau tidak begitu semangat saat harus mengerjakan tugas yang dibebankan kepadanya dalam kelompok (b) ketua dalam kelompok belum begitu dapat memaksimalkan tugasnya dalam memotivasi teman dalam kelompok untuk berpartisipasi dalam mengerjakan tugas yang diberikan kepada kelompok masingmasing, (c) dalam membacakan hasil diskusi kelompok, hanya siswa-siswa tertentu saja yang mau membaca. Berdasarkan hasil temuan tersebut maka pada siklus II yang 
menjadi masukan bagi peneliti untuk menjadi perbaikan agar hasil yang diperoleh menjadi lebih baik jika dibandingkan dengan siklus I adalah : (a) siswa dalam kelompok akan dijadikan berpasangan agar saat mengerjakan tugas siswa yang tidak begitu serius dapat dimotivasi melalui kegiatan tutor sebaya, memberikan kepercayaan yang lebih penuh kepada ketua dalam kelompok untuk memberikan kepercayaan dan keyakinan bagi setiap anggota dalam kelompoknya, (c) dalam membacakan hasil diskusi kelompok harus secara bergantian. Melihat hasil yang diperoleh pada siklus I belum sesuai dengan indikator yang telah ditentukan pada penelitian ini, maka penelitian ini dilanjutkan pada siklus berikutnya yaitu siklus II. Berdasarkan hasil tes yang dilakukan setelah siklus II selessai dilaksanakan sudah makin meningkat jika dibandingkan dengan hasil perolehan nilai pada kegiatan pada siklus I. Jika pada siklus I jumlah siswa yang berada pada interval nilai 60-69 berjumlah 6 siswa (25\%) maka pada siklus II hanya tinggal 2 siswa $(8,33 \%)$ dan kedua siswa tersebut adalah siswa yang juga belum tuntas dari 24 ju,lah siswa kelas V SD negeri 165725 kota Tebing Tinggi. Untuk interval nilai 70-79 jika pada siklus I hanya 12 siswa $(50 \%)$ maka pada siklus II hanya 9 siswa ( 37,5\%), interval 80-89 jika pada siklus I hanya 3 siswa (12,5\%) maka pada siklus II meningkat menjadi 10 siswa
$(41,66 \%)$ dan interval tertinggi yaitu 90 - 100 jika pada siklus I hanya ada 2 siswa ( 8,33\%) yang berhasil memperolehnya, maka pada siklus II untuk interval 90-100 ada 3 siswa $(12,5 \%) \quad$ yang berhasil memperolehnya Dari data tersebut terlihat kemampuan siswa meningkat setelah guru mengajar pendidikan kewarganegaraan dengan menggunakan model pembelajaran kooperatif tipe Students Team Achievement (STAD). Hal ini juga bisa kita lihat pada persentase pencapaian secara klasikal terhadap KKM yang telah ditentukan. Jika pada kegiatan siklus I pencapaian presentase secara klasikal hanya mencapai 70,83\% maka pada siklus II telah mencapai $91,66 \%$ terjadi peningkatan sekitar $20,83 \%$ jika dibandingkan dengan siklus II.

\section{Observasi}

Sama halnya dengan yang dilakukan pada siklus II bahwa pengamatan dalam penelitian ini dilihat dari berbagai instrumen penelitian, antara lain hasil tes kognitif siswa, lembar pengamatan terhadap ketrampilan siswa, dan pengamatan terhadap aktivitas siswa selama proses pembelajaran berlangsung. Dari hasil pengamatan yang dilakukan oleh observer dengan menggunakan lembar observasi yang telah disiapkan terlihat guru (peneliti) sudah melaksanakan seluruh aspek yang menjadi point pada lembar observasi. Hal ini sudah jauh lebih 
baik jika dibandingkan yang dilakukan pada siklus I, Baik dari proses pembelajaran yang dilakukan oleh guru, maupun aktifitas yang dilakukan siswa selama proses belajar mengajar berlangsung.

Refleksi

Refleksi dilakukan untuk mengetahui sejauh mana keberhasilan dari penerapan pembelajaran dengan menggunakan pembelajaran kooperatif tipe Students Team Achievement (STAD) yang telah dilakukan, mengetahui hasil belajar siswa pada siklus II, menganalisis aktivitas individual siswa dalam kelompok, mengetahui kendalakendala pada siklus II, serta mencari solusi dari kendala yang dihadapi untuk perbaikan pada siklus berikutnya. Adapun hasil refleksi yang dilakukan pada siklus II adalah sebagai berikut: (a) peneliti sudah terlihat lebih menguasai kelas dan mampu menggunakan model pembelajaran kooperatif tipe Students Team Achievement (STAD), (2) siswa telah lebih serius dan mulai terbiasa dengan menggunakan model pembelajaran kooperatif tipe Students Team Achievement (STAD) yang digunakan oleh guru setelah terjadi tutor sebaya dalam diskusi kelompok yang dilakukan secara berpasangan, (3) Guru telah mampu memaksimalkan penguasaan kelas saat proses pembelajaran berlangsung.
Pada tahap persiapan penelitian, peneliti menganalisis kondisi yang bertujuan untuk mengetahui ketersediaan alat dan bahan pembelajaran, kondisi kelas dan jumlah subjek penelitian. Media pembelajaran yang berkaitan dengan materi yang akan peneliti berikan ternyata cukup tersedia.Pada awal pertemuan sebelum siklus I dilaksanakan, peneliti melakukan pretes yang bertujuan untuk mengetahui kemampuan awal siswa sebelum penelitian dimulai. Nilai rata-rata pretes siswa pada mata pelajaran pendidikan kewarganegaraan materi kebebasan berorganisasi adalah 62,5 dengan persentase $41,66 \%$. Nilai yang diperoleh siswa pada hasil pretes pra siklus ini sangat rendah, hal ini disebabkan karena siswa belum diberikan materi pelajaran pendidikan kewarganegaraan dengan menggunakan model pembelajaran kooperatif tipe Students Team Achievement (STAD). Model yang diterapkan guru ini sangat berhasil, hal ini dapat dilihat dari hasil yang diperoleh pada siklus II ini nilai ratarata hasil belajar siswa sebesar 75,83 dengan presentase ketuntasan belajar siswa pada siklus II sebesar 91,66\% dan mencapai kriteria ketuntasan klasikal.Dari hasil siklus II ini dapat diperoleh kesimpulan bahwa dengan menggunakan model pembelajaran kooperatif tipe Students Team Achievement (STAD) dapat meningkatkan hasil belajar 
pendidikan kewarganegaraan khususnya pada materi kebebasan berorganisasi. Berdasarkan hasil tes yang diperoleh pada siklus II maka penelitian ini tidak perlu dilanjutkan lagi pada siklus berikutnya.

\section{SIMPULAN}

Berdasarkan hasil penelitian dan pembahasan yang disajikan dapat ditarik kesimpulan bahwa:

1. Hasil penelitian dengan menggunakan pembelajaran kooperatif tipe Students Team Achievement (STAD) terbukti dapat meningkatkan hasil pendidikan kewarganegaraan pada kebebasan berorganisasi siswa kelas V SD Negeri 165725 jalan Jenderal Sudirman kota Tebing Tinggi tahun pembelajaran 2015/2016.

2. Peningkatan hasil belajar pendidikan kewarganegaraan ini dapat dilihat dari hasil tes yang dilakukan selama penelitian berlangsung. Jika pada kegiatan pra siklus rata-rata perolehan nilai siswa sebesar 62,5 dengan ketuntasan klsikal 41,66\%, maka pada siklus I meningkat menjadi rata-rata penilaian siswa 69,78 dengan ketuntasan klasikal $70,83 \%$. Selanjutnya pada siklus II rata-rata perolehan nilai siswa 75,83 dengan ketuntasan klasikal $91,66 \%$. Terjadi peningkatan 13,3 terhadap rata-rata penilaian siswa dan $50 \%$ terhadap ketuntasan klasikal siswa, maka dengan ini penelitian ini dikatakan berhasil.

Dari hasil penelitian yang diperoleh dari uraian sebelumnya agar proses belajar mengajar pendidikan kewarganegaraan menjadi lebih efektif dan lebih memberikan hasil yang optimal bagi peserta didik, makan disampaikan saran sebagai berikut:

1. Untuk melaksanakan belajar dengan menggunakan pembelajaran kooperatif tipe Students Team Achievement (STAD) memerlukan persiapan yang cukup matang, sehingga guru harus mempu menentukan atau memilih topik yang benarbenar bisa diterapkan dalam proses belajar mengajar sehingga diperoleh hasil yang optimal.

2. Dalam rangka meningkatkan prestasi belajar peserta didik, guru hendaknya lebih sering melatih peserta didik dengan berbagai metode, walau dalam taraf yang sederhana, dimana peserta didik nantinya dapat menemukan pengetahuan baru, memperoleh konsep dan keterampilan, sehingga peserta didik berhasil atau mampu memecahkan masalah-masalah yang dihadapinya.

\section{DAFTAR RUJUKAN}

American College of Sport Medicine. 2008. ACSM's Health-Related Physical 
Fitness Manual 2nd ed. Philadelphia,PA: Lippincott Williams \& Wilkins. Available.from:http://ebook3 0. com/science/medicine/5095 9/acsrnshealthrelatedphysical fitness-assessmdnt manual. html (Accessed 2 July 2012)

Achmad Rifa'i R. C dan Catharina Tri Anni. 2010. Psikologi Pendidikan. Semarang: UNNES Press.

Departemen Pendidikan

Nasional. 2002. Kamus Umum

Bahasa Indonesia. Jakarta:

Balai Pustaka.

Djoko, Pekik. 2004. Pedoman Praktis Berolahraga untuk

Kebugaran dan

Kesehatan.Yogyakarta:

Andi Offset.

H. Y. S. Santoso G. Dan Dikdik Zafar S. 2012. Ilmu Faal Olahraga. (Fisiologi Olahraga). Bandung: PT Remaja Rosda Karya.

Khomsin (edt). 2010. Buku Panduan

Tes Kesegaran Jasmani Indonesia (TKJI). Jakarta:

Pusat Pengembangan Kualitas Jasmani.

Muhibbin, Syah. (2000). Psikologi Pendidikan dengan Suatu Pendekatan baru. Bandung: PT. Remaja Rosdakarya.

Sharkey, B.J. 2003. Fitness And Health. Alih bahasa Kebugaran dan Kesehatan oleh: Eri Desmarini Nasution. Jakarta: PT. Raja.
Grafindo Persada. Suharsimi Arikunto. 2002. Prosedur Penelitian Suatu Pendekatan Praktek. Jakarta: Rineka Cipta.

Sugiyono. 2009. Statistika untuk Penelitian. Bandung: Alfabeta. 